\title{
The seasonal variability of the amount of global solar radiation reaching the ground in urban and rural areas on the example of Warsaw and Belsk
}

Abstract

The aim of this paper is to determine the contemporary differences in the inflow of global solar radiation in Warsaw (urban station) and Belsk (rural station). The meteorological data used comprised daily sums of global solar radiation (in MJ•m${ }^{-2}$ ) and the duration of sunshine (in hours) for the period 2008 2014. On clear days in spring and summer, the rural area receives more solar radiation in comparison to the urban area, whereas in autumn a reverse relationship occurs. On cloudy days in all seasons, the rural area receives more solar radiation than the urban area, and the relationship is the strongest in winter. Differences between urban and rural areas on cloudy days are smaller than those observed on clear days.

Keywords

Global solar radiation $\cdot$ clear days $\cdot$ cloudy days $\cdot$ Warsaw $\cdot$ Belsk

(c) University of Warsaw - Faculty of Geography and Regional Studies

\author{
Kinga Nelken, Kamil Leziak \\ Department of Climatology \\ Faculty of Geography and Regional Studies \\ University of Warsaw \\ e-mail: kinganelken@uw.edu.pl \\ e-mail: k.leziak@uw.edu.pl \\ Received: 7 April 2016 \\ Accepted: 5 December 2016
}

\section{Introduction}

Solar radiation is the key component in the Earth's climate system and one of the most important variables in the surface's energy budget. Thus, it is essential to know the amount of solar radiation reaching the ground in areas of various land usage and with various factors of local climate, especially urban and rural areas. Studies on this subject have been conducted by Alpert et al. (2005), Alpert \& Kishcha (2008) and Wang et al. (2014), among others. Meanwhile, studies on the amount of global solar radiation in urban and rural areas (on both cloudy and clear days) have been conducted by Peterson and Stoffel (1980), Liepert (1997), Qian et al. (2006), and Robaa (2009). Due to a lack of data and problems with its acquisition, there are only a few similar studies focusing on Poland. Comparative studies of Warsaw and its surroundings have been carried out by Dziewulska-Łosiowa (1962), Krawczyk (1968), and Kozłowska-Szczęsna and Podogrocki (1995). Over the following years, studies on changes in the amount of solar radiation in urban and rural areas were also conducted in other cities, including Cracow (Bokwa \& Matuszyk 2007; Matuszko 2009), Puławy (Uscka-Kowalkowska 2008a), Łódź (Podstawczyńska 2007), Toruń (Kejna et al. 2014a \& 2014b), and complex studies of larger areas were performed in Wyżyna Śląsko-Krakowska (Caputa \& Leśniok 2009) and Pogórze Zachodniobeskidzkie (Matuszko \& Struś 2007). The latest studies focusing on Warsaw were carried out in 2003 (Błażejczyk \& Baranowski 2003). Both teams - Kozłowska-Szczęsna and Podogrocki, and Błażejczyk and Baranowski - concluded that the inflow of global solar radiation in Warsaw was lower than the inflow in the surrounding rural area.

In the analysis conducted by Kozłowska-Szczęsna and Podogrocki (1995), values of the solar radiation in the centre of Warsaw during the period 1961-1990 were compared to the corresponding values from the rural stations in Belsk and Brwinów. The authors observed that the annual sums of global solar radiation in the city were about $8-10 \%$ lower than outside the city, which is a difference of ca. $300 \mathrm{MJ} \cdot \mathrm{m}^{-2}$. The biggest differences occurred in winter (monthly sums of global solar radiation in Warsaw were $15 \%$ to $20 \%$ lower than those in Belsk and Brwinów), while in summer they were $3 \%$ to $10 \%$ lower (Kozłowska-Szczęsna \& Podogrocki 1995).

Błażejczyk and Baranowski (2003) compared the values of the global solar radiation in the centre of Warsaw to the values measured in Borowa Góra, 35 kilometres north-east of Warsaw. Despite using values from only a couple of days in the period 2000-2002, the results of their study were convergent with the results of previous studies. They concluded that the sums of the global solar radiation in the centre of the city are considerably lower than those measured in Borowa Góra, while the difference is bigger in winter $(9-14 \%)$ than in summer $(2-5 \%)$.

Because of the dynamic growth of urban spaces and the possibility of changes in urban climate factors, an analysis has been undertaken in order to verify the results of previous studies, using present-day actinometric data. The aim of this paper is to determine the contemporary differences in the inflow of global solar radiation (hereinafter, GSR, representing the allsky solar radiation reaching the Earth's surface) in urban and rural areas. This study focuses on the differences in the inflow of solar radiation on clear days - days when the amount of GSR depends primarily on the atmosphere's transparency and not on other factors, such as cloud cover. Studies on differences in the inflow of solar radiation in urban and rural areas are of great importance, application-wise, as part of solar climate analysis. The calculation of quantitative changes in the inflow of solar radiation to the surface in areas differentiated by the stage of urban development allows the determination of whether the urban climate is significantly different to the rural climate, and whether the reduced atmospheric transparency in the city causes important changes in the structure of the surface radiative budget. 
MISCELLANEA GEOGRAPHICA - REGIONAL STUDIES ON DEVELOPMENT

Vol. 20 • No. 4 • 2016 • pp. 29-37 • ISSN: 2084-6118 • DOI: 10.1515/mgrsd-2016-0022

Materials and methods

This paper uses meteorological data for the period 20082014 from three measuring stations. The main data was acquired from the station at the Institute of Geophysics at the University of Warsaw (referred to as IGF UW), located in Warsaw (Table 1), and from the station at the Institute of Geophysics at the Polish Academy of Science (referred to as Belsk), located in Belsk Duży (Table 1), about 50 kilometres south of the centre of Warsaw (Fig. 1). The IGF UW station represents the typical urban climate of a city centre, while the Belsk station is situated in a rural area, far away from any urban or industrial objects. Daily sums of GSR in $\mathrm{MJ} \cdot \mathrm{m}^{-2}$ were acquired from both stations; additionally, the duration of sunshine (in hours) was acquired from the Belsk station. Because the IGF UW station does not record sunshine duration, the sunshine duration data for Warsaw was acquired from the nearest available station, which is located at Warsaw Chopin Airport, called Warszawa-Okecie. The Warszawa-Okecie station is situated around 5 kilometres south of the IGF UW station. This may raise the question of whether this data can properly reflect sunshine conditions at the IGF UW station, but research has shown that the number of clear days is almost the same at Warszawa-Okęcie and in the city centre (Kossowska-Cezak 1978).

It should be noted that GSR data at both stations was collected using Kipp \& Zonen pyranometers, which fully comply with the 'High quality' standard issued by the World Meteorological Organization for meteorological instruments, according to ISO norm no. 9060:1990 (ISO 1990). In Belsk, the CM21 model with a directional error of $<10 \mathrm{~W} \cdot \mathrm{m}^{-2}$ was used, while in Warsaw, the CMP22 model with a directional error of $<5 \mathrm{~W} \cdot \mathrm{m}^{-2}$ was used. Both sensors have an instability of $<0.5 \% \cdot \mathrm{yr}^{-1}$, so it can be concluded that, after their initial calibration, there was no significant change in their accuracy over the research period. Both pyranometers were installed on the rooftops with full hemispherical view (sky view factor $=1$ ). Despite the high accuracy of both pyranometers, the authors are aware of the possible inaccuracies caused by the differences in GSR detected by both instruments. In particular, the authors are aware that up to $2 \%$ of the difference in the amount of GSR in Warsaw and Belsk might be caused by uncertainties of the CM21 and CMP22 sensors (see: Vuilleumier et al. 2014). However, uncertainty error is always present in the results of any type of in situ measurement, including solar radiation measurement. It should also be noted that the sunshine duration in Belsk was recorded with a Campbell-Stokes recorder with a minimum sensitivity threshold of $279.2 \mathrm{Wm}^{-2}$ (Kuczmarski 1990), while at Warszawa-Okęcie station an electronical recorder with a minimum sensitivity threshold of $120 \mathrm{Wm}^{-2}$ (Maciążek 2004) was used. All data has been checked for incorrect and missing values.

Daily sums of the extra-terrestrial solar radiation and potential sunshine duration were also used in this study. Appropriate values for Warsaw and Belsk were calculated using the formula described by Duffie and Beckmann (2013). This method for calculating extra-terrestrial (potential) solar radiation was also used by Robaa (2009) and Kejna et al. (2014a), and the results are convergent with the values determined by other methods (Owczarek 1993, 1997, 2002; Bzowska \& Kossecka 1993). On the basis of the measured values of the GSR and sunshine duration in Warsaw and Belsk, and the values of potential GSR and potential sunshine duration, the values of relative GSR and relative sunshine duration in percentages were calculated for both locations.

Because differences in the inflow of solar radiation between Warsaw and Belsk may be related to differences in cloud cover, two sets of data were chosen for further comparative analysis: clear days and cloudy days. Clear days were determined as days with a relative sunshine duration of $80 \%$ or above concurrently at both stations. Maximum values of relative sunshine duration never reach $100 \%$, and clear days (days without limitation to
Table 1. Location of the meteorological stations included in the study

\begin{tabular}{|c|c|c|c|}
\hline Station & $\boldsymbol{\varphi} \mathbf{N}$ & $\lambda \mathrm{E}$ & $\begin{array}{c}\text { Altitude } \\
\text { (MASL) }\end{array}$ \\
\hline IGF UW & $52^{\circ} 12^{\prime} 43^{\prime \prime} \mathrm{N}$ & $20^{\circ} 59^{\prime} 00^{\prime \prime} \mathrm{E}$ & 148 \\
\hline Warszawa-Okęcie & $52^{\circ} 09^{\prime} 46^{\prime \prime} \mathrm{N}$ & $20^{\circ} 57^{\prime} 39^{\prime \prime} \mathrm{E}$ & 105 \\
\hline Belsk & $51^{\circ} 50^{\prime} 10^{\prime \prime} \mathrm{N}$ & $20^{\circ} 47^{\prime} 34^{\prime \prime} \mathrm{E}$ & 188 \\
\hline
\end{tabular}

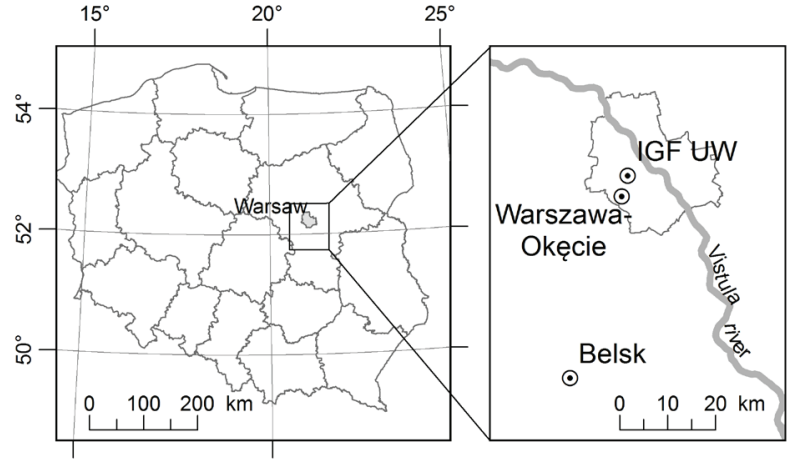

Figure 1. Location of the urban and rural stations included in the study. Source: own elaboration

the inflow of solar radiation) are often described as days with a relative sunshine duration of at least $75 \%$ (Podstawczyńska 2007), or days with a mean daily cloud cover of less than $20 \%$ (Wu et al. 2012; Fu et al. 2015). Cloudy days were determined as days with a relative sunshine duration of precisely $0 \%$ concurrently at both stations; only days with an actual $0 \%$ of relative sunshine duration were taken into account, excluding days when the zero value was caused by a lack of data (Podstawczyńska 2007; Matuszko 2009). The number of clear and cloudy days in individual seasons is given in Table 2. Additionally, a comparative analysis was performed on the whole set of data for the period 2008-2014, including days that were neither clear nor cloudy, as a background for the results obtained in the mentioned data subsets. Differences were calculated between the sums of the GSR in Warsaw and Belsk, as well as differences between the sums of the relative solar radiation in Warsaw and Belsk, separately for clear days, cloudy days and all days in the period 2008-2014. The observed differences were analysed in individual seasons. The statistical significance of the differences at the significance level $\alpha=0.05$ was tested with the Mann-Whitney U-test.

Results

All days in the period 2008-2014

Over the whole seven-year period, the difference between annual sums of GSR in Warsaw and Belsk was below zero, which means that the urban station received a lower inflow of solar radiation than the rural station (Table 3 ). The difference ranged from $99.93 \mathrm{MJ} \cdot \mathrm{m}^{-2}$ in 2014 to $153.19 \mathrm{MJ} \cdot \mathrm{m}^{-2}$ in 2011 . The mean annual difference reached $125.03 \cdot \mathrm{MJ} \cdot \mathrm{m}^{-2}$ in favour of the rural station in Belsk. The mean annual difference calculated as a percentage of the value in Belsk (the station with higher values) reached $3.5 \%$, while the greatest difference occurred in $2013(4.5 \%)$ and the smallest in 2014 (2.6\%). In Łódź, the mean difference between urban and rural sites is 4.6\% (Podstawczyńska 1997), and in Cairo 3.5\% (Robaa 2009), in favour of the rural site. In 
Table 2. Number of clear and cloudy days occurring at IGF UW and Belsk stations concurrently, for the period 2008-2014. Additionally, the number of clear and cloudy days at each station is presented, for the period 2008-2014

\begin{tabular}{|c|c|c|c|c|c|c|}
\hline \multirow{2}{*}{ Season } & \multicolumn{2}{|c|}{ Concurrently } & \multicolumn{2}{c|}{ IGF UW } & \multicolumn{2}{c|}{ Belsk } \\
\cline { 2 - 7 } & Clear days & Cloudy days & Clear days & Cloudy days & Clear days & Cloudy days \\
\hline spring (III-V) & 67 & 43 & 179 & 48 & 70 & 102 \\
\hline summer (VI-VIII) & 58 & 17 & 201 & 19 & 144 & 12 \\
\hline autumn (IX-XI) & 10 & 112 & 110 & 308 & 5 & 296 \\
\hline winter (XII-II) & 4 & 239 & 29 & 519 & 151 & 595 \\
\hline year (I-XII) & 139 & 411 & 519 & & & \\
\hline
\end{tabular}

Table 3. Differences between the annual sums of GSR (in MJ $\mathrm{m}^{-2}$ and \%) at the urban station, IGF UW, and the rural station, Belsk, for the period 2008-2014

\begin{tabular}{|c|c|c|c|c|c|c|c|c|}
\hline & $\mathbf{2 0 0 8}$ & $\mathbf{2 0 0 9}$ & $\mathbf{2 0 1 0}$ & $\mathbf{2 0 1 1}$ & $\mathbf{2 0 1 2}$ & $\mathbf{2 0 1 3}$ & $\mathbf{2 0 1 4}$ & $\mathbf{2 0 0 8 - 2 0 1 4}$ \\
\hline difference $\left(\mathrm{MJ} \cdot \mathrm{m}^{-2}\right)$ & -117.29 & -132.10 & -126.69 & -153.19 & -124.02 & -122.00 & -99.93 & -125.03 \\
\hline difference $(\%)$ & -3.3 & -3.3 & -3.4 & -3.7 & -3.5 & -4.5 & -2.6 & -3.5 \\
\hline
\end{tabular}

Mexico City, one of the biggest cities in the world, this difference reaches 10\% (Galindo 1962 cited in Robaa 2009).

The course of the differences between mean daily sums of GSR in the period 2008-2014 was prepared as absolute values $\left(\mathrm{MJ} \cdot \mathrm{m}^{-2}\right)$ (Fig. 2) and relative values (as a percentage of the value in Belsk, the station with the higher values) (Fig. 3). On particular days there were occasional differences in favour of the station in Warsaw, coinciding with a greater duration of sunshine in the city. This can be explained by the difference in the cloud cover in Warsaw and Belsk - there is a more intense formation of convective clouds over Belsk than over Warsaw. This specific synoptic situation, with major differences in the daily sums of GSR favouring the urban station, occurred in only around $7 \%$ of cases. Nevertheless, the maximum values of those differences were much lower than the maximum values of differences in favour of the station in Belsk. Furthermore, filtering the values using a 31day-long simple moving average clearly indicates that the amount of GSR in Belsk was always higher than in Warsaw. Furthermore, a correlation mentioned by Podstawczyńska (2007) was noticed: the differences between the absolute values of GSR at the two stations were greater in the warm half-year, while differences between relative values were greater in the cold half-year.

The mean monthly differences and maximum differences of the mean daily sums of GSR between the urban station in Warsaw and the rural station in Belsk were calculated (Table 4). The mean monthly differences in absolute values were smallest from October to December - when they did not exceed $0.2 \mathrm{MJ} \cdot \mathrm{m}^{-2}$ - and greatest from June to July (surpassing $0.55 \mathrm{MJ} \cdot \mathrm{m}^{-2}$ ). The mean annual difference in absolute values reached $0.37 \mathrm{MJ} \cdot \mathrm{m}^{-2}$. The greatest mean daily difference occurred in April (15.32 $\left.\mathrm{MJ} \cdot \mathrm{m}^{-2}\right)$. The mean monthly differences in relative values (calculated as a percentage of the value in Belsk - the station with the higher values) were greatest in winter. From December to February they exceeded $8 \%$, while the maximum value of the mean daily difference occurred in January (12.0\%). In spring and summer the monthly mean differences were smaller than $4 \%$. The mean annual difference in relative values reached $5 \%$, but the greatest mean daily difference $-25.9 \%$ - occurred in January.

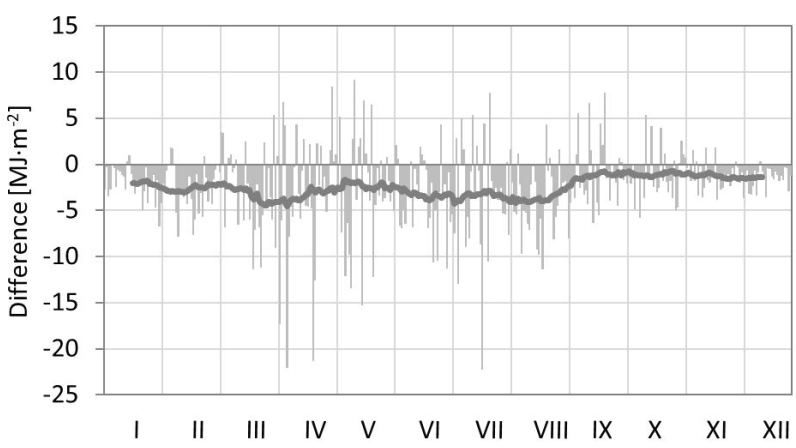

Figure 2. Differences between the mean daily sums of GSR (in $M J \cdot m^{-2}$ ) at the urban station, IGF UW, and the rural station, Belsk, for the period 2008-2014. The solid grey line represents the 31-day-long simple moving average. Source: own elaboration

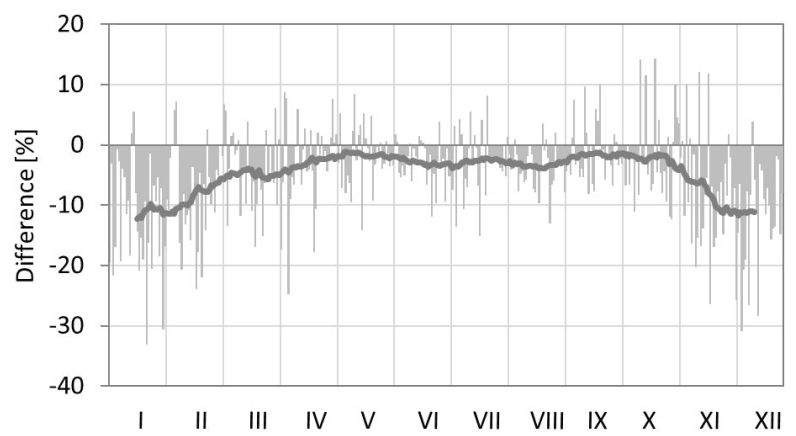

Figure 3. Differences between the mean daily sums of GSR (in \%) at the urban station, IGF UW, and the rural station, Belsk, for the period 2008-2014. The solid grey line represents the 31-day-long simple moving average. Source: own elaboration 
MISCELLANEA GEOGRAPHICA - REGIONAL STUDIES ON DEVELOPMENT

Vol. 20 • No. 4 • 2016 • pp. 29-37 • ISSN: 2084-6118 • DOI: 10.1515/mgrsd-2016-0022

Table 4. The mean and the biggest mean differences between the daily sums of GSR (in $M J \cdot m^{-2}$ and \%) at the urban station, IGF UW, and the rural station, Belsk, for the period 2008-2014

\begin{tabular}{|c|c|c|c|c|c|c|c|c|c|c|c|c|c|}
\hline & I & II & III & IV & V & VI & VII & VIII & IX & X & XI & XII & I-XII \\
\hline mean $\left(\mathrm{MJ} \cdot \mathrm{m}^{-2}\right)$ & -0.30 & -0.43 & -0.38 & -0.57 & -0.29 & -0.55 & -0.59 & -0.60 & -0.20 & -0.18 & -0.15 & -0.20 & -0.37 \\
\hline $\max \left(\mathrm{MJ} \cdot \mathrm{m}^{-2}\right)$ & -4.07 & -3.63 & -6.98 & -15.32 & -12.14 & -8.24 & -13.95 & -9.82 & -8.67 & -4.28 & -2.40 & -2.07 & -15.32 \\
\hline $\operatorname{mean}(\%)$ & -12.0 & -8.7 & -3.9 & -3.8 & -1.6 & -2.6 & -3.0 & -3.4 & -1.8 & -2.8 & -5.6 & -10.9 & -5.0 \\
\hline $\max (\%)$ & -25.9 & -17.6 & -11.1 & -14.2 & -4.5 & -5.0 & -6.5 & -6.2 & -7.3 & -9.1 & -11.6 & -20.8 & -25.9 \\
\hline
\end{tabular}

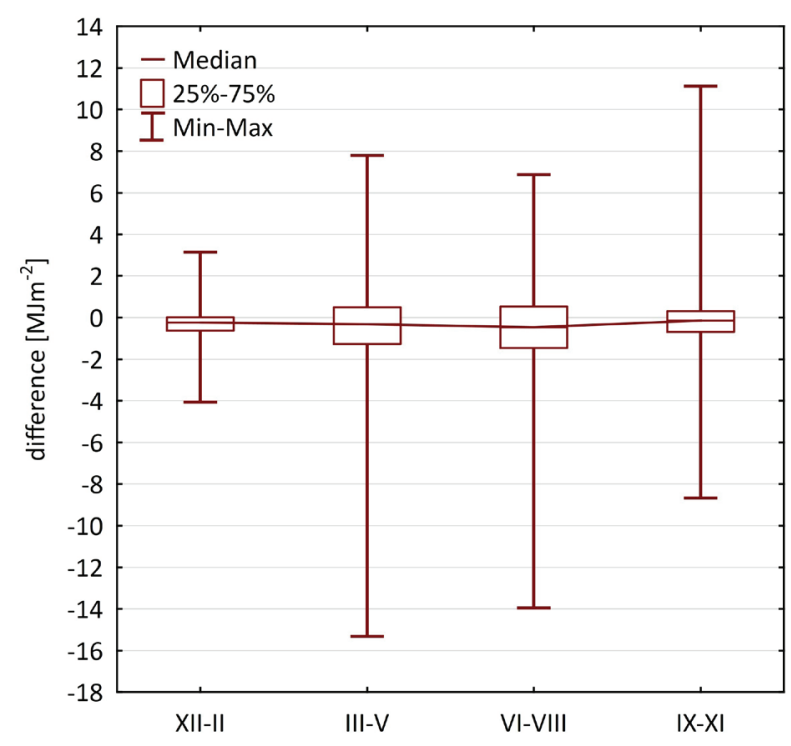

Figure 4. Differences (in $M J \cdot m^{-2}$ ) between the daily sums of GSR at the urban station, IGF UW, and the rural station, Belsk, in each season, for the period 2008-2014. The median value and quartiles are presented. Source: own elaboration

A statistical analysis was conducted of the variation in differences between the daily sums of GSR in Warsaw and Belsk in individual seasons (Fig. 4). In every season (hereinafter, XII-II stands for winter, III-V for spring, VI-VIII for summer and IX-XI for autumn) the median had a negative value, which suggests an increased inflow of solar radiation in Belsk in comparison to Warsaw. Meanwhile, in every season (excluding winter), the absolute value of the negative deviation was greater than the absolute value of the positive deviation.

Equations of the simple linear regressions for the relationships between the daily sums of GSR in Warsaw and Belsk in each season were determined on the basis of scatter plots (Fig. 5). In all regression equations the slope coefficient is smaller than one, at a significance level determined by the $p$-value which is, in this case, smaller than 0.0001 . However, the $95 \%$ regression coefficient confidence interval ranged from below 0.9 to above 1.0 , meaning that the value of the regression coefficient is not statistically different from 1 . Meanwhile, the coefficient of determination $r^{2}$ of the regression equation exceeds 0.90 for spring, summer and autumn, and 0.89 for winter, which means that, in the period 2008-2014, around $90 \%$ of the variance of GSR in Warsaw was explained by variation of GSR in Belsk.
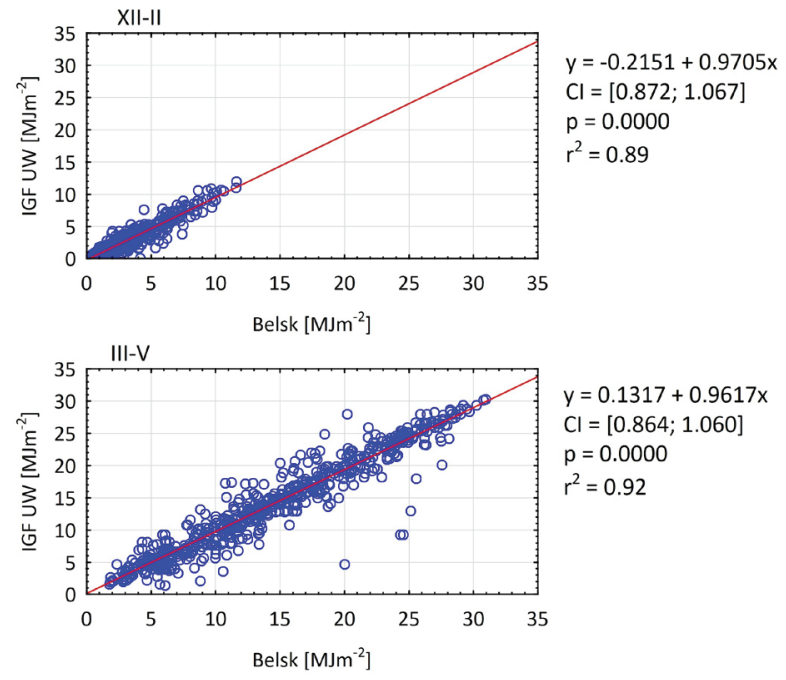

$y=0.1317+0.9617 x$ $\mathrm{Cl}=[0.864 ; 1.060]$ $\mathrm{p}=0.0000$ $r^{2}=0.92$

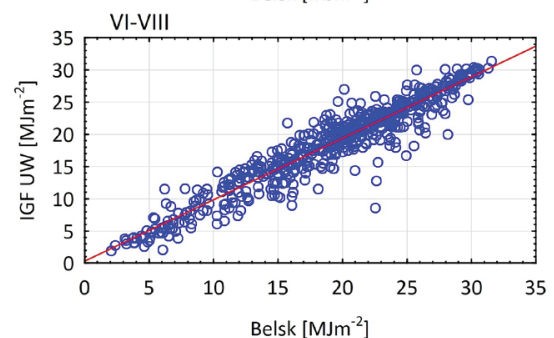

$y=0.3338+0.9527 x$ $\mathrm{Cl}=[0.854 ; 1.051]$ $p=0.0000$ $r^{2}=0.90$

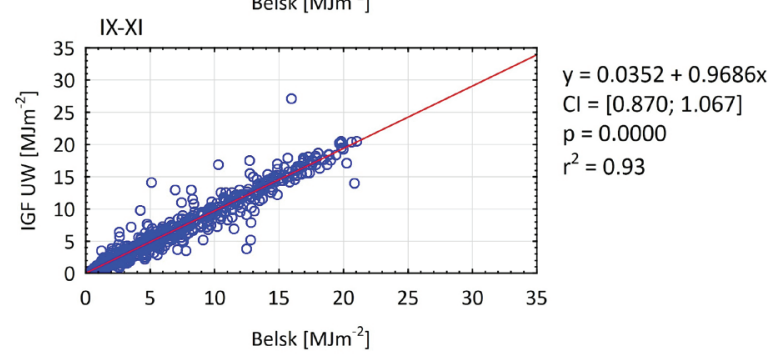

Figure 5. Relationships between the daily sums of GSR (in $\left.M J \cdot m^{-2}\right)$ at the urban station, IGF UW, and the rural station, Belsk, in each season, for the period 2008-2014. The red line represents the simple linear regression. On the right hand side of each graph there is the regression equation, the $95 \%$ regression coefficient confidence interval (Cl), the $p$-value that represents the significance level, and the coefficient of determination $r^{2}$. Source: own elaboration 
Table 5. Mean monthly values of relative solar radiation (in \%) at the urban station, IGF UW, and the rural station, Belsk, and the difference (in percentage points) between these stations, for the period 2008-2014. Statistically significant differences ( $\alpha=0.05)$ are written in bold

\begin{tabular}{|c|c|c|c|c|c|c|c|c|c|c|c|c|c|}
\hline & I & II & III & IV & V & VI & VII & VIII & IX & X & XI & XII & I-XII \\
\hline IGF UW & 27.3 & 35.3 & 42.6 & 46.1 & 46.8 & 49.2 & 48.4 & 49.0 & 45.9 & 38.9 & 25.8 & 25.8 & 40.1 \\
\hline Belsk & 30.1 & 36.8 & 43.5 & 47.9 & 47.8 & 50.1 & 50.6 & 50.9 & 45.7 & 39.9 & 26.8 & 28.1 & 41.5 \\
\hline difference & $\mathbf{- 2 . 8}$ & -1.5 & -0.9 & -1.8 & -1.0 & -0.9 & -2.2 & -1.9 & 0.2 & -1.0 & -1.0 & $-\mathbf{2 . 3}$ & $\mathbf{- 1 . 4}$ \\
\hline
\end{tabular}

The annual courses of the daily sums of extra-terrestrial (potential) solar radiation and the mean daily sums of GSR in Warsaw and Belsk were determined (Fig. 6). The mean annual value of relative solar radiation reached $40.1 \%$ in Warsaw and $41.5 \%$ in Belsk (Table 5). Similar values for the mean annual relative solar radiation in Toruń and its surroundings were calculated by Kejna et al. (2014b): $44.8 \%$ for the rural station and $40.7 \%$ for the urban station. The difference between the values of relative solar radiation in Warsaw and Belsk was negative for the majority of the year, which confirmed the presumption that rural areas are privileged in terms of the inflow of solar radiation in comparison to urban areas. A slightly positive difference occurred in September only ( 0.2 of a percentage point), whereas the greatest negative differences occurred in January and December ( -2.8 and -2.3 percentage points, respectively). These were also the only statistically significant differences.

\section{Clear days}

During the period 2008-2014, 139 days were classified as clear at both stations concurrently, but only 135 days were taken for further analysis (4 winter days were rejected). Due to the relatively small number of clear days in the given time period, it was impossible to determine the differences in the inflow of solar radiation on a long-term (annual) or monthly basis, but statistical analysis was conducted of the mean differences in individual seasons (Fig. 7). In spring and summer, negative values occurred more often, which suggests that in these seasons the rural station was privileged in terms of solar radiation; the median reached $-0.34 \mathrm{MJ} \cdot \mathrm{m}^{-2}$ in spring and $-0.56 \mathrm{MJ} \cdot \mathrm{m}^{-2}$ in summer. During clear days, the absolute values of negative deviations were greater than the absolute values of positive deviations a similar situation to the one previously described for the set of all days. Autumn was a particularly distinctive season, during which a small positive difference occurred, meaning Warsaw received a similar inflow of solar radiation to Belsk. The values from autumn had a smaller scatter and their median reached $0.03 \mathrm{MJ} \cdot \mathrm{m}^{-2}$. This can be explained by the change of air humidity in urban and rural areas in this particular season (the decrease in the amount of water vapour in the air over the city compared to the air over the rural area). Certain authors have mentioned the seasonal differences in humidity between the city and its surroundings, and their influence on the atmospheric turbidity (Lee 1991; Kuttler et al. 2007; Dudek et al. 2010). Furthermore, in autumn there may be a noticeable increase in air dustiness over rural areas. An analysis of the situation in winter was not conducted, since only 4 concurrent clear days occurred in Warsaw and Belsk over the whole period of 2008-2014.

Equations of the simple linear regressions for relationships between the values of GSR in Warsaw and Belsk during clear days in each season were determined and the scatter plots were computed (Fig. 8). Equations of the simple linear regression for spring and summer had slope coefficients smaller than one, with coefficients of determination $r^{2}$ equal to 0.93 and 0.90 ,
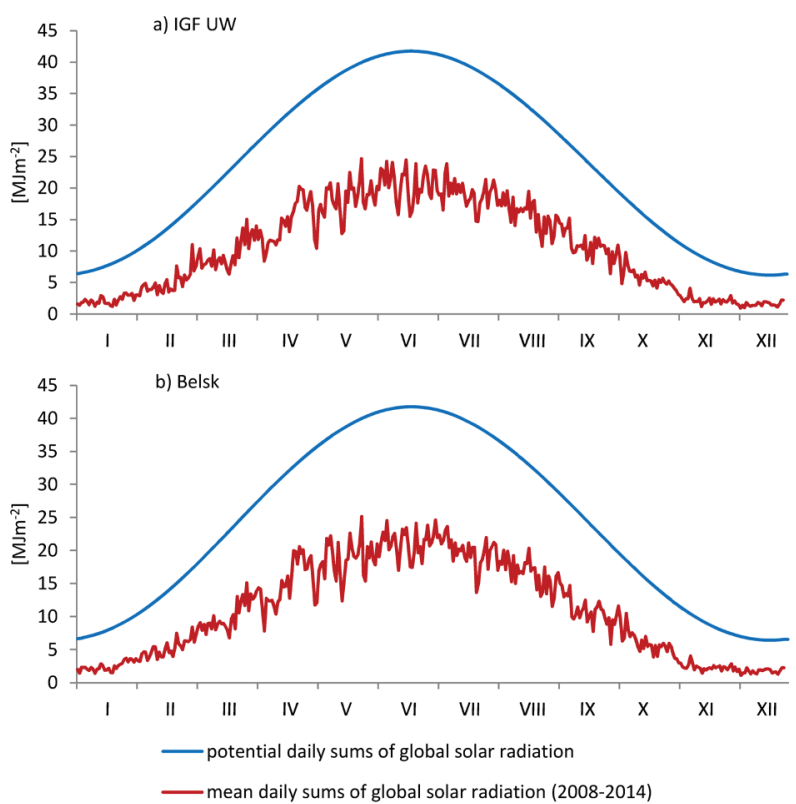

Figure 6. Annual course of potential daily sums of solar radiation (in $\mathrm{MJ} \cdot \mathrm{m}^{-2}$ ) and mean daily sums of GSR for the period 20082014 (in $\mathrm{MJ} \cdot \mathrm{m}^{-2}$ ) at the urban station, IGF UW, (a) and the rural station, Belsk (b). Source: own elaboration

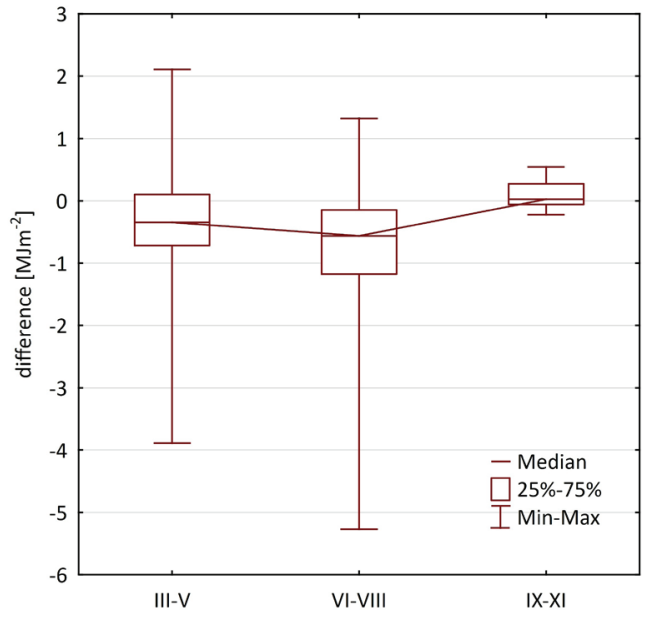

Figure 7. Differences (in $M J \cdot m^{-2}$ ) between the daily sums of GSR at the urban station, IGF UW, and the rural station, Belsk, on clear days in each season, for the period 2008-2014. The median value and quartiles are presented. Source: own elaboration 
respectively, which means that around $93 \%$ (in spring) or $90 \%$ (in summer) of the variance of GSR in Warsaw was explained by variation of GSR in Belsk. It should be noted, however, that the $95 \%$ regression coefficient confidence interval ranged (for spring and summer) from below 0.9 to above 1.0, meaning that the value of the regression coefficient is not statistically different from 1. In autumn the urban station is privileged in terms of solar radiation (the slope coefficient reaches 1.05 with a coefficient of determination equal to 0.998 ), which confirms the previous results shown in Fig. 7, although it should be emphasized that there were only a few clear days in autumn. All regression equations are statistically significant at a significance level smaller than 0.0001 .

The smallest mean relative solar radiation in Warsaw occurred in summer, the greatest in spring and autumn (Table 6). In spring, the altitude of the Sun above the horizon is large and comparable to summer, while the transparency of the atmosphere is higher than in summer because of the lower amount of aerosols and water vapour in the air (Uscka-Kowalkowska 2008b). Olecki (1975, 1992) and Uscka-Kowalkowska (2008a) determined a coefficient of atmospheric transmitivity for other Polish cities, indicating that the lowest transmitivity occurs in summer and the highest in autumn and winter. Similar results have been obtained in Hong Kong (Li\&Lam2002), Cairo(Robaa2009)and Sao Paulo(DosSantos\&Escobedo 2016). The relationships observed in Belsk were slightly different, because the relative solar radiation in the rural area was slightly higher in summer and smaller in autumn (Table 6). Due to different thermal characteristics and the roughness of the land surface in the city (compared to the rural conditions), as well as increased air pollution, an increased turbidity and positive lower atmosphere buoyancy can be observed (Shuzhen et al. 1991; El-Wakil et al. 2001). Changes in the atmospheric turbidity influence the results of the measurements, because pyranometers are located below the planetary boundary layer - that is, within the most polluted layer of the atmosphere. There are also other factors that can influence the results of GSR measurements, such as the inflow of various air masses with different thermodynamic characteristics or local air pollution emissions. The authors are aware of the complexity of the relationships between the inflow of solar radiation and various elements of the climate system on the local scale and the mesoscale. However, due to limitations in the availability of data, it was not possible to explicitly determine all functional relationships that lead to changes in the amount of GSR in various weather conditions.

\section{Cloudy days}

In the period 2008-2014, 411 days were classified as cloudy at both stations concurrently. In all seasons, the median of the set of differences between the GSR in Warsaw and Belsk was below zero, which suggests that the rural station in Belsk was privileged in terms of solar radiation (Fig. 9). The absolute values of negative deviations in winter, summer and autumn were greater than the absolute values of positive deviations, while the relationship was reversed in spring.

Equations of the simple linear regressions for relationships between the daily sums of GSR in Warsaw and Belsk on cloudy days in each season were determined and scatter plots were computed (Fig. 10). In all cases, the slope coefficients of the equations of the simple linear regressions were considerably smaller than one, which indicates that Belsk was privileged in terms of solar radiation in comparison to Warsaw. The strongest statistically significant relationship occurred in winter (slope coefficient equal to 0.67 with coefficient of determination equal to 0.77 ), the weakest in spring (slope coefficient equal to 0.78 with coefficient of determination equal to 0.53). The relationship in summer, despite having an extraordinary small slope coefficient value, is not statistically significant at the significance level

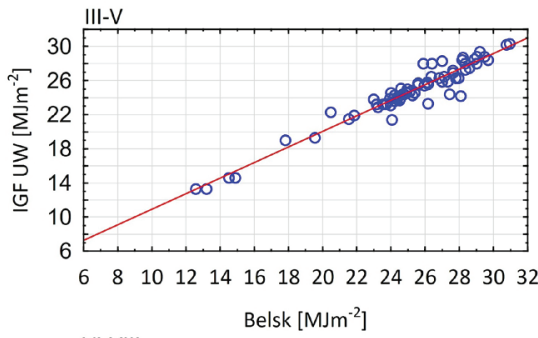

$y=1.7919+0.913 x$

$\mathrm{Cl}=[0.813 ; 1.046]$

$p=0.0000$

$r^{2}=0.93$

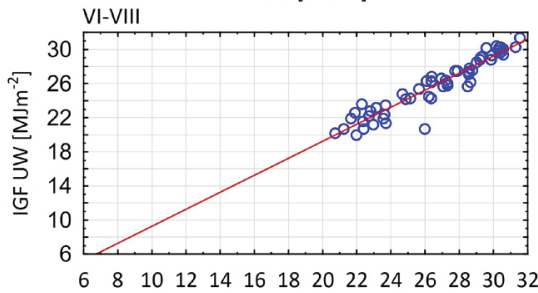

$y=-0.7104+0.9979 x$

$\mathrm{Cl}=[0.898 ; 1.099]$

$p=0.0000$

$r^{2}=0.90$

Belsk $\left[\mathrm{MJm}^{-2}\right]$

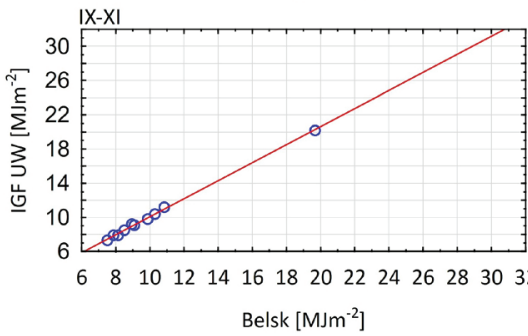

$y=-0.4517+1.0538 x$

$\mathrm{Cl}=[0.985 ; 1.123]$

$\mathrm{p}=0.0000$

$r^{2}=0.998$

Figure 8. Relationships between the daily sums of GSR (in $M J \cdot m^{-2}$ ) at the urban station, IGF UW, and the rural station, Belsk, on clear days in each season, for the period 2008-2014. The red line represents the simple linear regression. On the right hand side of each graph there is the regression equation, the 95\% regression coefficient confidence interval $(\mathrm{Cl})$, the $p$-value that represents the significance level, and the coefficient of determination $r^{2}$. Source: own elaboration

Table 6. Mean seasonal value of relative solar radiation (in \%) at the urban station, IGFUW, and the rural station, Belsk, during clear days, and the difference (in percentage points) between these stations, for the period 2008-2014. The statistically significant difference $(\alpha=0.05)$ is written in bold.

\begin{tabular}{|c|c|c|c|}
\hline & III-V & VI-VIII & IX-XI \\
\hline IGF UW & 70.1 & 66.1 & 68.7 \\
\hline Belsk & 71.8 & 68.1 & 67.3 \\
\hline difference & -1.7 & $\mathbf{- 2 . 0}$ & 1.4 \\
\hline
\end{tabular}

$\alpha=0.05$. All other regression equations are statistically significant at the significance level determined by the $p$-value - in this case, smaller than 0.0001

During cloudy days, the inflow of solar radiation is of course smaller than during clear days, but, similarly to clear days, a major decrease in the inflow of solar radiation occurs in summer, both in Belsk and Warsaw (Table 7). On average, during cloudy days, only $14.1 \%$ of the extra-terrestrial radiation reaches the Earth's surface in Warsaw, while in Belsk it is slightly more $-16.7 \%$. The lower value in Warsaw was caused in particular by the deficiency of GSR observed in urban conditions in winter (-3.9 percentage points), due to the synergetic effect of the atmospheric extinction caused by low-etage stratiform clouds and the increased 


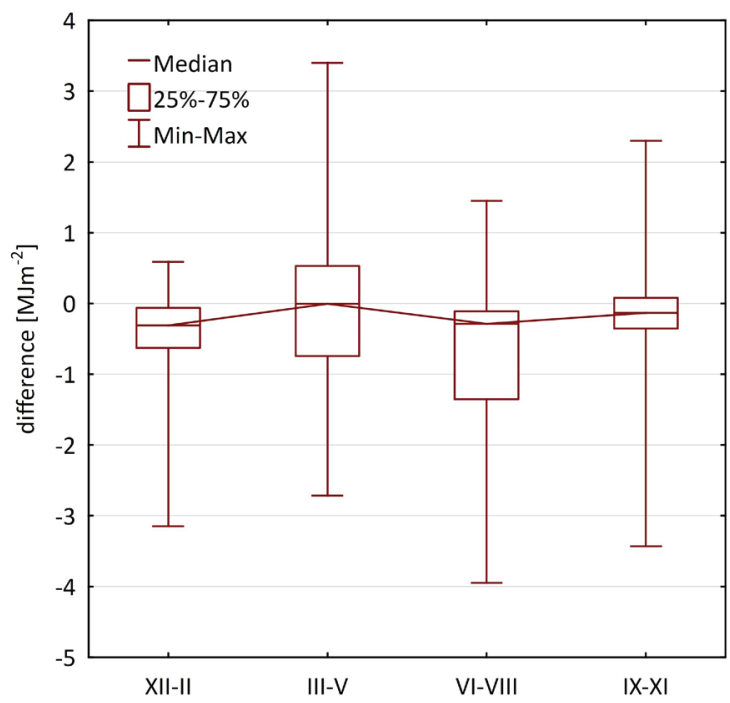

Figure 9. Differences (in $M J \cdot m^{-2}$ ) between the daily sums of GSR at the urban station, IGF UW, and the rural station, Belsk, on cloudy days in each season, for the period 2008-2014. The median value and quartiles are presented. Source: own elaboration

concentration of air pollution related to the intensive usage of heating systems. Comparing the values of relative solar radiation obtained for clear and cloudy days, it can be concluded that slightly greater differences between the urban and rural stations occurred during clear days, regardless of the season. The reason for this lies in the reduced transmitivity of the atmosphere over big cities, which is more noticeable during cloudless days. Differences between Warsaw and Belsk on cloudy days are smaller. It should be noted, however, that this analysis was conducted on the basis of days classified as cloudy at both stations concurrently, while the turbidity of the atmosphere contributes to an increase in the amount of condensation nuclei and, consequently, to an increase in cloudiness and the number of days with total cloud cover in big cities (Romanov 1999). Unfortunately, due to the differences in the minimum sensitivity threshold of the sunshine duration recorders used at Belsk and Warszawa-Okęcie, it is not possible to unequivocally determine such a relationship on the basis of the available data.

\section{Conclusions}

The results of the study confirm the regularities described by other researchers (see: Kozłowska-Szczęsna \& Podogrocki 1995; Błażejczyk \& Baranowski 2003), according to which the inflow of solar radiation in the urban area is smaller than the inflow of solar radiation in the rural area. The $3.5 \%$ surplus of GSR in the rural area is similar to the value of $4.6 \%$ in Łódź (Podstawczyńska 2007) and smaller than $7 \%$ in Cracow (Bokwa \& Matuszyk 2007). Based on the set of all days in the period 2008-2014, the increase in the absolute values of differences between the stations in the warm half-year was confirmed, as was the increase in the relative values of differences in the cold half-year. The computed values of relative solar radiation and its differences between Warsaw and Belsk are similar to the values calculated for other Polish cities (Kejna et al. 2014b). When only clear days are taken into account, the following can be stated: in spring and summer, the rural area is privileged in terms of solar radiation in comparison to the urban
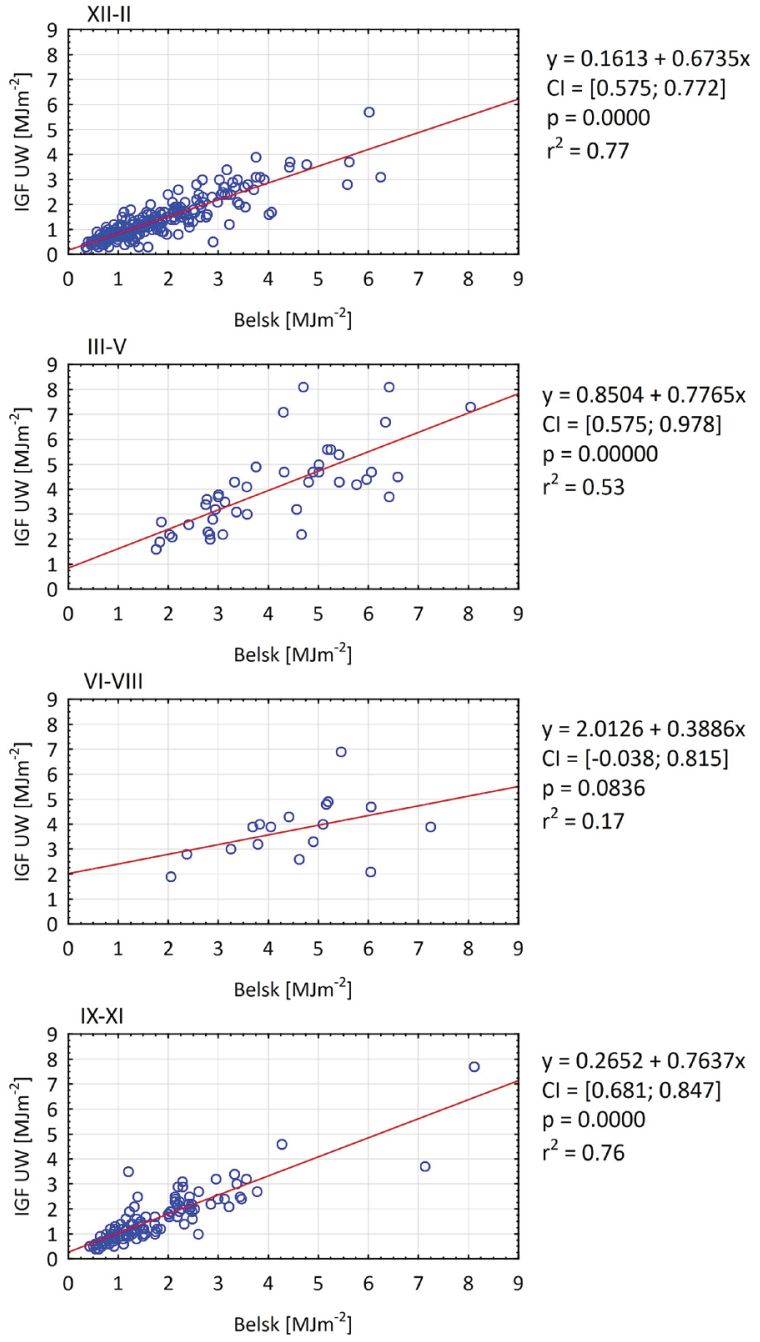

Figure 10. Relationships between the daily sums of GSR (in $M J \cdot m^{-2}$ ) at the urban station, IGF UW, and the rural station, Belsk, on cloudy days in each season, for the period 2008-2014. The red line represents the simple linear regression. On the right hand side of each graph there is the regression equation, the 95\% regression coefficient confidence interval $(\mathrm{Cl})$, the $p$-value that represents the significance level, and the coefficient of determination $r^{2}$. Source: own elaboration

Table 7. Mean seasonal value of relative solar radiation (in \%) at the urban station, IGF UW, and the rural station, Belsk, during cloudy days, and the difference (in percentage points) between these stations, for the period 2008-2014. Statistically significant differences $(\alpha=0.05)$ are written in bold.

\begin{tabular}{|c|c|c|c|c|c|}
\hline & III-V & VI-VIII & IX-XI & XII-II & I-XII \\
\hline IGF UW & 15.2 & 9.8 & 13.0 & 14.7 & 14.1 \\
\hline Belsk & 15.8 & 11.7 & 13.8 & 18.6 & 16.7 \\
\hline difference & -0.5 & -2.0 & -0.8 & $\mathbf{- 3 . 9}$ & $\mathbf{- 2 . 6}$ \\
\hline
\end{tabular}


area, whereas in autumn, the reverse relationship occurs and the urban area receives slightly more solar radiation than the rural area. It can be concluded that, during cloudy days in all seasons, the rural area receives more solar radiation than the urban area, with this relationship being strongest in winter. The differences between the urban and rural areas on cloudy days are smaller than those observed for clear days. It is important to point out, however, that the differences between urban and rural conditions as a whole are small, and in many cases not statistically significant. In order to get a better understanding of the reasons for variations in the inflow of solar radiation in urban sites and rural background areas, it is necessary to extend the series of observations. With a data sequence that is long enough and of a proper quality, one can try to determine the quantitative relationships between the amount of GSR reaching the surface and the values of other meteorological parameters like air temperature, humidity and visibility.

\section{References}

Alpert, P, Kishcha, P, Kaufman, YJ \& Schwarzbard, R 2005 , 'Global dimming or local dimming?: Effect of urbanization on sunlight availability', Geophysical Research Letters, vol. 32, L17802. DOI 10.1029/2005GL023320.

Alpert, P \& Kishcha, P 2008, 'Quantification of the effect of urbanization on solar dimming', Geophysical Research Letters, vol. 35, L08801. DOI 10.1029/2007GL033012.

Błażejczyk, K \& Baranowski, J 2003, 'Solar and UV radiation in the Warsaw Downtown' in Proceedings of Fifth International Conference on Urban Climate, eds K Kłysik, T Oke, K Fortuniak, S Grimmond \& J Wibig, Łódź, vol. 1, pp. 263-268.

Bokwa, A \& Matuszyk, K 2007, 'Zmiany promieniowania całkowitego w Krakowie i Gaiku-Brzezowej', Pamiętnik Puławski, vol. 144, pp. 5-12.

Bzowska, D \& Kossecka, E 1993, Analiza promieniowania słonecznego w Warszawie waspekcie energetyki słonecznej, Wydawnictwo Spółdzielcze, Warszawa.

Caputa, Z \& Leśniok, M 2009, 'Struktura bilansu promieniowania na obszarach miejskich i wiejskich - system pomiarowy i wybrane wyniki pomiarów na Wyżynie Śląsko-Krakowskiej', Prace Geograficzne UJ, vol. 122, pp. 23-38.

Dos Santos, CM \& Escobedo, JF 2016, 'Temporal variability of atmospheric turbidity and DNI attenuation in the sugarcane region, Botucatu/SP', Atmospheric Research, vol. 181, pp. 312-321. DOI 10.1016/j.atmosres.2016.07.012.

Dudek, S, Kuśmierek-Tomaszewska, R \& Żarski, J 2010, 'Characteristics of urban heat island on the example of Bydgoszcz', Ekologia i technika, vol. 18, no. 4, pp. 180-185.

Duffie, JA \& Beckmann, WA 2013, Solar engineering of thermal processes, John Wiley \& Sons, Hoboken, New Jersey.

Dziewulska-Łosiowa, A 1962, ‘Próba oceny zakłócenia przezroczystości atmosfery w Warszawie', Przegląd Geofizyczny, vol. VII, no. 2, pp. 111-116.

El-Wakil, SA, El-Metwally, M \& Guyermard, C 2001, 'Atmospheric turbidity of urban and desert areas of the Nile Basin in aftermath of Mt. Pinatubo's eruption', Theoretical and Applied Climatology, vol. 68, pp. 89-108.

Fu, C , Dan, L, Chen, Y \& Tang, J 2015, 'Trends of the sunshine duration and diffuse radiation percentage on sunny days in urban agglomerations of China during 1960-2005', Journal of Environmental Sciences, vol. 34, pp. 206-211. DOI 10.1016/j.jes.2014.08.027.

Galindo, I 1962, La radiacion en Mexico en 1957, UNAM, Instituto de Geafisica. Cited in Robaa, SM 2009, 'Urban-rural solar radiation loss in the atmosphere of Greater Cairo region, Egypt', Energy Conversion and Management, vol. 50, no. 1, pp. 194-202. DOI 10.1016/j.enconman.2008.06.024.

ISO, International Organization for Standardization, 1990, Solar Energy - Specification and Classification of Instruments for Measuring Hemispherical Solar and Direct Solar Radiation, ISO 9060:1990.

Kejna, M, Uscka-Kowalkowska, J \& Araźny, A 2014a, 'Bilans promieniowania w Koniczynce koło Torunia w latach 2011-
2012', Przegląd Naukowy - Inżynieria i Kształtowanie Środowiska, vol. 63, pp. 26-42.

Kejna, M, Uscka-Kowalkowska, J, Araźny, A, Kunz, M, Maszewski, R \& Przybylak, R 2014b, 'Spatial differentiation of global solar radiation in Torun and its suburban area (central Poland) in 2012', Bulletin of Geography - Physical Geography Series, no. $7 / 2014$, pp. 27-56.

Kossowska-Cezak, U 1978, 'Próba określenia wpływu zabudowy miejskiej na wielkość zachmurzenia (na przykładzie Warszawy)', Prace i Studia IG UW, vol. 25, pp. 55-63.

Kozłowska-Szczęsna, T \& Podogrocki, J 1995, 'Antropogeniczne zmiany warunków radiacyjnych w Warszawie' in Klimat bioklimat miast, ed K Kłysik, Wydawnictwo Uniwersytetu Łódzkiego, Łódź, pp. 87-97.

Krawczyk, B 1968, 'Badania zmętnienia atmosfery w Warszawie w latach 1961-1963', Przegląd Geofizyczny, vol. XI, no. 4, pp. 823-832.

Kuczmarski, M 1990, 'Usłonecznienie Polski i jego przydatność dla helioterapii', Dokumen-tacja Geograficzna, vol. 4, Wydawnictwo PAN, Wrocław, Warszawa, Kraków.

Kuttler, W, Weber, S, Schonnefeld, J \& Hesselschwerdt, A 2007, 'Urban/rural atmospheric water vapour pressure differences and urban moisture excess in Krefeld, Germany', International Journal of Climatology, vol. 27, no. 14, pp. 2005-2015. DOI 10.1002/joc.1558.

Lee, DO 1991, 'Urban-rural humidity differences in London', International Journal of Climatology, vol. 11, no. 5, pp. 577-582. DOI 10.1002/joc.3370110509.

Li, DHW \& Lam, JC 2002, 'A study of atmospheric turbidity for Hong Kong', Renewable Energy, vol. 25, no. 1, pp. 1-13. DOI 10.1016/S0960-1481(01)00008-8.

Liepert, BG 1997, 'Recent changes in solar radiation under cloudy conditions in Germany', International Journal of Climatology, vol. 17, pp. 1581-1593. DOI 10.1002/(SICl)1097-0088 (19971130)17:14<1581::AID-JOC214>3.0.CO;2-H.

Maciążek, A 2004, Aparatura pomiarowa w służbie, IMGW, Warszawa.

Matuszko, D 2009, Wpływ zachmurzenia na usłonecznienie i całkowite promieniowanie słoneczne na przykładzie krakowskiej serii pomiarów, Wydawnictwo Uniwersytetu Jagiellońskiego, Kraków.

Matuszko, D \& Struś, P 2007, ‘Przestrzenne zróżnicowanie warunków solarnych Pogórza Zachodniobeskidzkiego (próba metodyczna)', Pamiętnik Puławski, vol. 144, pp. 105-113.

Olecki, Z 1975, 'Oddziaływanie dużego ośrodka miejskoprzemysłowego na dopływ promieniowania słonecznego (na przykładzie Krakowa)', Zeszyty Naukowe UJ, vol. 414, Prace Geograficzne, no. 41, pp. 37-86.

Olecki, Z 1992, 'Przezroczystość atmosfery w krakowskiej aglomeracji miejsko-przemysłowej', Zeszyty Naukowe UJ, vol. 1152, Prace Geograficzne, no. 90, pp. 23-34.

Owczarek, S 1993, Model gęstości energii promieniowania słonecznego na dowolną płaszczyzne. Identyfikacja dla Warszawy, Wydawnictwo Spółdzielcze, Warszawa. 
Owczarek, S 1997, 'Vector model for calculation of solar radiation intensity and sums incedent on tilted surfaces. Identification for three sky conditions in Warsaw', Renevable Energy, vol. 11 , no. 1, pp. 77-96.

Owczarek, S 2002, Identyfikacja modelu promieniowania słonecznego dla 10-ciu stacji aktynometrycznych na terenie Polski. Wyniki obliczeń wartości godzinowych i dziennych promieniowania na wybrane płaszczyzny, Wydawnictwo Spółdzielcze, Warszawa.

Qian, Y, Kaiser, DP, Leung, LR \& Xu, M 2006, 'More frequent cloud-free sky and less surface solar radiation in China from 1955 to 2000', Geophysical Research Letters, vol. 33, L01812, DOI 10.1029/2005GL024586.

Peterson, JT \& Stoffel, TL 1980, 'Analysis of urban-rural radiation data from St. Louis Missouri', Journal of Applied Meteorology, vol. 19, pp. 275-283.

Podstawczyńska, A 2007, Cechy solarne klimatu Łodzi, Wydawnictwo Uniwersytetu Łódzkiego, Łódź.

Robaa, SM 2009, 'Urban-rural solar radiation loss in the atmosphere of Greater Cairo region, Egypt', Energy Conversion and Management, vol. 50, no. 1, pp. 194-202. DOI 10.1016/j.enconman.2008.06.024.

Romanov, P 1999, 'Urban influence on cloud cover estimated from satellite data', Atmospheric Environment, vol. 33, no. 24-25, pp. 4163-4172. DOI 10.1016/S1352-2310(99)00159-4.

Shuzhen, Z, Djen, SC \& Jingchun, Z 1991, 'The turbidity island effect in Shanghai urban climate', Energy and buildings, vol. 16, no. 1-2, pp. 657-662. DOI 10.1016/03787788(91)90034-Z.
Uscka-Kowalkowska, J 2008a, Bezpośrednie promieniowanie słoneczne i jego ekstynkcja w atmosferze na przykładzie Puław i Papowa Toruńskiego, Wydawnictwo Naukowe Uniwersytetu Mikołaja Kopernika, Toruń.

Uscka-Kowalkowska, J 2008b, 'Bezpośrednie promieniowanie słoneczne i jego ekstynkcja w atmosferze w Kołobrzegu w latach 1960-2000', Acta Agrophysica, vol. 12, no. 1, 221233.

Vuilleumier, L, Hauser, M, Felix, C, Vignola, F, Blanc, P, Kazantzidis, A \& Calpini, B 2014, Accuracy of ground surface broadband shortwave radiation monitoring, Journal of Geophysical Research Atmospheres, vol. 119, issue 24, pp. 13838-13860. DOI 10.1002/2014JD022335

Wang, K, Ma, Q, Wang, XY \& Wild, M 2014, 'Urban impacts on mean and trend of surface incident solar radiation', Geophysical Research Letters, vol. 41, pp. 4664-4668, DOI 10.1002/2014GL060201.

Wu, J, Fu, CB, Zhang, LY \& Tang, JP 2012, 'Trends of visibility on sunny days in China in the recent 50 years', Atmospheric Environment, vol. 55, pp. 339-342. DOI 10.1016/j. atmosenv.2012.03.037. 